University of Nebraska - Lincoln

DigitalCommons@University of Nebraska - Lincoln

Papers in the Earth and Atmospheric Sciences Earth and Atmospheric Sciences, Department

7-1959

On the status of Theocampe Haeckel, and certain similar genera

Benjamin H. Burma

University of Nebraska-Lincoln

Follow this and additional works at: https://digitalcommons.unl.edu/geosciencefacpub

Part of the Earth Sciences Commons

Burma, Benjamin H., "On the status of Theocampe Haeckel, and certain similar genera" (1959). Papers in the Earth and Atmospheric Sciences. 324.

https://digitalcommons.unl.edu/geosciencefacpub/324

This Article is brought to you for free and open access by the Earth and Atmospheric Sciences, Department of at DigitalCommons@University of Nebraska - Lincoln. It has been accepted for inclusion in Papers in the Earth and Atmospheric Sciences by an authorized administrator of DigitalCommons@University of Nebraska - Lincoln. 
ABstRAGT: This paper is a revision of the generic nomenclature of a few radiolarian genera whose species are good zone and index fossils. The following genera are revised more or less extensively: Sethamphorus, Sethocephala, Dictyocephalus, Theocampe, and Tricolocampe. The following names are reduced to synonomy: Dictyocryphalus, Cryptocephalus, Dictyoprora (1882), Platycryphalus, Dictyoprora (1887), Theocamptra, Theocampana, Tricolocampium, Tricolocamptra, and Theocampula. Diabolocampe is described as a new genus.

\section{On the status of Theocampe Haeckel, and certain similar genera}

BENJAMIN H. BURMA

California Exploration Company

San Francisco, California
This paper primarily concerns the proper generic name to be applied to an important and compact group of species typified by several species referred to Dictyocephalus (Dictyoprora) by Clark and Campbell (1942, pl. 8, figs. 2-4, 6-8), and other papers. For reasons developed below, this group of species is properly referred to Theocampe Haeckel, 1887, but a number of rather tangled nomenclatural problems are involved.

Theocampe was erected in 1887 by Haeckel, who did not designate type species for any of his numerous genera and subgenera. This lack was remedied for Theocampe in 1954 by Campbell, who validly designated Dictyomitra ehrenbergi Zittel, 1876. Zittel's specimens of this species were, by his own statement, not very well preserved, and his figure of it shows little other than the general outline. This figure, together with his description, is enough, however, to show that the species is a member of the species group with which we are concerned. It is of particular interest that Zittel specifically compared Dictyomitra ehrenbergi with Eucyrtidium mongolfieri Ehrenberg, which I would refer to Theocampe. According to Zittel, the only feature separating the two species, which would now be given generic status, is that his species has a threesegmented shell, and Ehrenberg's a two-segmented one. Actually, both Ehrenberg's and Clark and Campbell's species are three-jointed, contrary to their descriptions, so that their species can all be referred unequivocally to Theocampe. (Eucyrtidium s.s., and Dictyoprora s.s. are quite different from Theocampe).
At the same time that Theocampe was described, Haeckel erected two subgenera within it, Theocampana and Theocamptra, neither with a designated type species. Since Dictyomitra ehrenbergi was listed under the former subgenus, Theocampana in 1954 automatically became an objective synonym of Theocampe. In 1954, Campbell erroneously cited Theocampula Haeckel, 1887, as this objective synonym. Haeckel did not mention the name Theocampula, so the subgenus must be credited to Campbell as of 1954. Since it is listed as an objective synonym of Theocampe, it plainly has Dictyomitra ehrenbergi Zittel, 1876, as its type species. In case it should be considered that Campbell's citation is not clear enough, I here designate Dictyomitra ehrenbergi Zittel as the type species of Theocampula Campbell, 1954.

With these two subgenera disposed of, there remains Theocamptra. Campbell (1954) validly designated Theocampe (Theocamptra) collaris Haeckel, 1887, as its type species. Haeckel, followed by Campbell, separated the two subgenera of Theocampe on the basis of the relative size of the thoracic and abdominal pores, which are of similar size in Theocampe s.s. and of dissimilar sizes in Theocamptra. My experience with the group has convinced me that, for this group, the distinction is trivial, and at most a species character. On the other hand, two distinct shell types have been included under Theocampe. One of these characterizes the species group that includes Theocampe ehrenbergi, which has a hyaline peristomal collar. The other species group, which lacks such a collar and differs in other important 
ways from Theocampe s.s., is typified by Theocampe stenostoma Haeckel, 1887, illustrated by Campbell (1954) in his text-figure 69-6 and supposedly typical of Theocampe.

The type species of Theocamptra plainly belongs to the species group to which Dictyomitra ehrenbergi belongs and thus, by definition, to the genus Theocampe. The type species of both subgenera have a hyaline collar, the same shape, and the same number of segments. Theocamptra is therefore to be considered a subjective synonym of Theocampe, and Theocampe then becomes a genus without subgenera. It is redefined below. The species group including "Theocampe" stenostoma is thus left temporarily without a name, and is also considered below.

In text-figure 69-7 of Campbell (1954) a species listed as Tricolocampe (actually T. cylindrica Haeckel, 1887) is illustrated. Tricolocampe was erected by Haeckel in 1882. Rüst (1885) seems to have been the first to refer species to the genus, and the first one he listed was Tricolocampe clepsydra. Campbell (1954) cited this species as the type (but misspelled it "clypsydra"). I have not come across an earlier designation of this species as the type species, and Campbell did not make an actual designation. If there has been no prior unequivocal designation, I hereby designate Tricolocampe clepsydra Rüst, 1885 (p. 37, pl. 37, fig. 3) as the type species of Tricolocampe. Tricolocampe clepsydra has characteristics unfortunately all too common among type species. In his original description, Rüst states that the species occurs as steinkerns, and that the pores cannot be made out on them. From my own experience, I can state that such material is usually useless for study, and that Rüst's species must be considered unidentifiable. As its type species is unidentifiable, Tricolocampe is best left as a disused monotypic genus.

"Tricolocampe" was credited with two subgenera by Haeckel (1887): Tricolocampium and Tricolocamptra. With Tricolocampe an unrecognizable genus, these two groups are best considered genera. According to Campbell (1954), Tricolocampium is an objective synonym of Tricolocampe. Tricolocampe clepsydra Rüst is not one of the species listed under Tricolocampium, and therefore the two cannot be objective synonyms; Tricolocampe clepsydra is unavailable for the type species of Tricolocampium. I therefore designate Tricolocampe (Tricolocampium) cylindrica Haeckel, 1887 (p. 1412, pl. 66, fig. 21), as the type species of Tricolocampium. The only difference between Theocampe and Tricolocampium is that the latter has a less inflated abdomen. I can only regard this as a species character, and I therefore consider Tricolocampium a subjective synonym of Theocampe.

Tricolocamptra (type species T. urnula Haeckel, 1887, designated by Campbell, 1954) is very similar to Tricolocampium. The difference between the two is in the relative sizes of the thoracic and abdominal pores. As in Theocampe, I consider this difference a species character in this group, and would therefore reduce Tricolocamptra to the status of a subjective synonym of Theocampe.

In their series of papers published in 1942, 1944, and 1945, Campbell and Clark described a number of species under the subgenus Dictyocephalus (Dictyoprora). All of these species were supposed to have only two shell segments, but close inspection of the illustrations leaves little doubt that these species have three segments and are correctly to be referred to Theocampe. In 1953, Campbell recognized that Dictyoprora, as used above, was a homonym, and he named Streptodelus, with type species Dictyocephalus amphora Haeckel, 1887, to replace it. He evidently meant this to be the subgeneric name for the species described by Clark and himself under Dictyoprora, as mentioned above. Dictyocephalus (D.) amphora, judging from Haeckel's detailed illustration, is a form with only two shell segments. This is apparently a valid species group to recognize, but it is quite distinct from the species described by Campbell and Clark in their prior papers.

Since Riedel (1957) used Sethamphora as the generic name for a species which I would refer to Theocampe, a consideration of the name Sethamphora becomes necessary. Sethamphora was erected by Haeckel in 1887. He divided it into two subgenera, Dictyoprora Haeckel, 1882, and Cryptocephalus Haeckel, 1882. Rüst, in 1885, first assigned a species to Cryptocephalus, $C$. exiguus, which becomes the type species by monotypy. Dictyoprora was cited by Campbell (1954) as having Sethamphora hexapleura as its type species. I have not come across the prior designation of this species as type, and Campbell does not unequivocally do so. If this has not been properly done heretofore, I hereby designate, as the type species of Dictyoprora, Sethamphora (Dictyoprora) hexapleura Haeckel, 1887 (p. 1250). None of the species listed by Haeckel under this subgenus was illustrated by him. The difference between these two subgenera is supposed to be that Cryptocephalus has the cephalus submerged in the thorax, whereas it is emergent in Dictyoprora. Unfortunately, the type species of Cryptocephalus clearly has an emergent cephalus, so that the two subgenera are synonymous. Furthermore, with regard to both type species, neither the 
illustrations nor Rüst's descriptions indicate anything other than a ribless shell. The two subgenera therefore cannot be distinguished from Dictyocephalus s.s Ehrenberg, 1860, and become subjective synonyms of that genus.

Thus the species listed under the subgenus Dictyoprora by Haeckel (1887) are to be removed to the genus Dictyocephalus (D.) (or Theocampe, in part, actually). This leaves the two species which he described under the subgenus "Cryptocephalus." These two species have submerged cephali and therefore cannot be referred to Cryptocephalus s.s. (or Dictyoprora). They must then be assigned to Sethamphora s.s. Of the two species, I designate Sethamphora favosa Haeckel, 1887 (p. 1252, pl. 57, fig. 4), as the type species of Sethamphora. Campbell (1954) listed Sethamphora as an objective synonym of Cryptocephalus. Since Rüst's species is not among those listed by Haeckel under Sethamphora, this cannot be true, and, as indicated above, Cryptocephalus has an emergent cephalus and Sethamphora a submergent one.

To round off this phase of the discussion, two other genera must be considered. Platycryphalus was named by Haeckel in 1882. In 1885, Rüst first assigned a species to the genus, $P$. pumilus, which becomes the type species by monotypy. The differences between $P$. pumilus and Cryptocephalus exiguus are relatively trivial and on the species level. Platycryphalus is here considered a subjective synonym of Cryptocephalus and Dictyocephalus (D.). Again, in 1954, Campbell listed Sethocephalus as an objective synonym of Platycryphalus. Sethocephalus was first proposed by Haeckel in 1887 as a substitute for Platycryphalus Haeckel, 1882 , which would not ordinarily be allowable. In the meantime, Rüst, as we have seen above, inadvertently made Platycryphalus the name of a species group quite different from the sort put under the name Sethocephalus by Haeckel. Haeckel (1887) described two species under the latter name. Sethocephalus eucecryphalus, one of them, is a tintinnid, now assigned to Cyttarocyclis. The other species, Sethocephalus platycryphalus Haeckel, 1887, is here designated the type species of Sethocephalus (p. 1298, no illustration but similar in form to pl. 55, fig. 3 ). Sethocephalus cannot be an objective synonym of Platycryphalus, in any case, as Haeckel did not include the species $P$. pumilus under Sethocephalus.

Finally, a word must be said regarding the type species of Dictyocephalus. The genus name was first used by Ehrenberg in a table in 1860(a) (p. 767) in the combinations Dictyocephalus Capito and Dictyocephalus galeatus. On page 823 (Ehrenberg, 1860 b), also in a table, used the combinations, successively, of Dictyocephalus Capito, Dictyocephalus aculeatus, Dictyocephalus gracilis, Dictyocephalus laxus and Dictyocephalus Pyrum. Finally, on page 830 (Ehrenberg, $1860 b$ ) Dictyocephalus was given its first description as a new genus. In this section, the first species mentioned as belonging to the genus is Lophophaena obtusa. This latter species was designated as the type species of Dictyocephalus by Campbell (1954). On the face of it, six other species have prior claim to the title over Dictyocephalus obtusus. All of these six species were, however, nomina nuda in 1860 to the best of my knowledge. Dictyocephalus aculeatus, Dictyocephalus Capito and Dictyocephalus galeatus were finally described, as new species in 1872 (Ehrenberg, 1872). Dictyocephalus gracilis, Dictyocephalus laxus and Dictyocephalus Pyrum are apparently still nomina nuda. Lophophaena obtusa, on the other hand, was listed and well illustrated in "Mikrogeologie" (Ehrenberg, 1854) six years earlier, and is thus the first available species. I would thus agree with Campbell's designation except that I would date the species from 1854 rather than 1860 .

The only group of species not yet discussed and pertinent to our present purpose is that of such species as "Theocampe" stenostoma, mentioned above. These species are herein named Diabolocampe (see below).

We may now summarize the discussion given above as follows:

\section{Phylum PROTOZOA}

Class ACTINOPODA

Subclass RADIOLARIA

Order OSCULOSIDA

Suborder NASSELLINA

Family SETHOPHORMIDIDAE

Subfamily SETHOPHORMIDINAE

Genus Sethamphorus Haeckel, 1887, emend. Burma Cryptocephalus auct. (pars).

Type species: Sethamphora favosa Haeckel, 1887 (p. 1252, pl. 57, fig. 4), here designated.

Derivation and gender: Greek - sieve-pitcher, masculine (originally transliterated as Sethamphora (feminine) by Haeckel).

Definition: Sethophormids with ovate shell and restricted mouth; cephalis submerged in thorax; numerous more or less well-developed ribs but no free feet.

Geologic range: Jurassic to Miocene. 
Genus Sethocephala Haeckel, 1887, emend. Burma

Type species: Sethocephalus platycryphalus Haeckel, 1887 (p. 1298, no illustration), here designated.

Derivation and gender: Greek - sieve-head, feminine (originally transliterated as Sethocephalus by Haeckel).

Definition: Large cephalus without apical horn; flat, expanded, discoidal thorax.

Geologic range: Recent.

Family LOPHOPHAENIDAE

\section{Subfamily LOPHOPHAENINAE}

Genus Dictyocephalus Ehrenberg, 1860, emend. Burma

Type species: Dictyocephalus obtusus Ehrenberg, 1854, designated by Campbell (1954).

Derivation and gender: Greek - latticed head, feminine (originally transliterated as Dictyocephalus by Ehrenberg).

Synonyms: See under the subgenera.

Definition: Lophophaenids with free cephalus, without a horn. Mouth simple, thorax ovate to cylindrical.

Geologic range: Cambrian to Recent.

Subgenus Dictyocephala Ehrenberg, emend. Burma

Dictyocryphalus HAEckel, 1882.

Cryptocephalus HAEckel, 1882.

Dictyoprora HAEckel, 1882 (non Haeckel, 1887).

Platycryphalus HAEckel, 1882.

Definition: Dictyocephalids whose mouth is not at the end of a hyaline collar.

Geologic range: Cambrian to Recent.

Subgenus Streptodelus Campbell, 1953

Dictyoprora HaEckel, 1887 (non Haeckel, 1882).

Type species: Dictyocephalus amphora Haeckel, 1887, by original designation.

Derivation and gender: Greek - clear or evident collar, masculine.

Definition: Dictyocephalids whose mouth is at the end of a hyaline collar.

Geologic range: Eocene to Recent.

Family THEOCORYTHIDAE

Subfamily THEOCORYTHINAE

Genus Theocampe Haeckel, 1887, emend. Burma

Theocamptra HAEckel, 1887.

Theocampana HAECKEL, 1887.
Tricolocampium HAECKeL, 1887.

Tricolocamptra HAEGKel, 1887.

Theocampula CAMpbell, 1954.

Eucyrtidium auct. (pars).

Dictyocephalus (Dictyoprora) auct. (pars, especially Campbell and Clark).

Not Dictyocephalus (Streptodelus), sensu its type species.

Sethamphora auct. (pars).

Type species: Dictyomitra ehrenbergi Zittel, 1876, designated by Campbell (1954).

Derivation and gender: Greek - divine caterpillar, feminine.

Definition: Theocorythids without a cephalic horn, smooth except for abdominal ribs in some species and papillae in others. The three segments typically fused, especially the cephalus and thorax, less well shown in the type species than in many others. All segments poriferous in known species; pores of the cephalus and thorax slant outward and downward toward the mouth in many species; abdominal pores show a strong tendency to be arranged in a square horizontal and vertical grid, may be in horizontal rows but not vertically aligned, or in a quincuncial pattern, or uncommonly without a pattern. Abdomen typically swollen, but subcylindrical in species formerly referred to "Tricolocampe." Mouth narrower than the abdomen, at the end of a longer or shorter but distinct, clear hyaline collar. Shell as a whole of a glassy clarity when well preserved.

Geologic range: Maestrichtian to Recent, cosmopolitan.

Species presently referred to the genus:

Dictyocephalus (Dictyoprora) santaemonicae Campbell and Clark, 1944; Tortonian, Valmonte diatomite, California.

Dictyocephalus (Dictyoprora) miralestensis Campbell and Clark, 1944; Tortonian, Valmonte diatomite, California.

Dictyocephalus (Dictyoprora) obesus Clark and Campbell, 1942; lower Auversian, Kellogg shale, California.

Dictyocephalus (Dictyoprora) longicollis Clark and Campbell, 1942; lower Auversian, Kellogg shale, California.

Dictyocephalus (Dictyoprora) pulcherrimus pulcherrimus Clark and Campbell, 1942; Bartonian, Sidney shale, California.

Dictyocephalus (Dictyoprora) pulcherrimus curtus Clark and Campbell, 1942; Bartonian, Sidney shale, California.

Dictyocephalus (Dictyoprora) callimorphos Clark and Campbell, 1945; Bartonian-Ludian, Kreyenhagen shale, California.

Dictyocephalus (Dictyoprora) eos Clark and Campbell, 1945; Bartonian, Kreyenhagen shale, California.

Dictyocephalus (Dictyoprora) lipogaster Clark and Campbell, 1945; Bartonian-Ludian, Kreyenhagen shale, California.

?Dictyocephalus (Dictyoprora) urceolus Haeckel, 1887; Central Pacific Station 268, Eocene-Oligocene of Barbados (?Eucyrtidium mongolfieri of Bury). 
Dictyomitra ehrenbergi Zittel, 1876; Maestrichtian, Germany; type of Theocampe (Theocampe).

Theocampe (Theocamptra) collaris Haeckel, 1887; South Pacific Station 295 (type of Theocamptra).

Theocampe (Theocamptra) costata Haeckel, 1887; Sunda Straits, surface, Recent.

?Lithocampe (Lithocampium) ovata Haeckel, 1887; Western Tropical Pacific Station 225.

Eucyrtidium mongolfieri Ehrenberg, 1873; Eocene-Oligocene, Barbados.

Eucyrtidium gemmatum Ehrenberg, 1873; Eocene-Oligocene, Barbados.

Eucyrtidium pirum Ehrenberg, 1873; Eocene-Oligocene, Barbados.

Eucyrtidium panthera Ehrenberg, 1875; Eocene-Oligocene of Barbados; Atlantic and Pacific Oceans.

Tricolocampe (Tricolocampium) cylindrica Haeckel, 1887; Central Pacific Stations 265 to 274.

?Tricolocampe (Tricolocampium) pupa Ehrenberg, 1872; Tropical Pacific Station 206.

? Tricolocampe (Tricolocampium) polyzona Haeckel, 1887; Central Pacific Stations 266-272; fossil in Nicobars and Barbados.

? Tricolocampe (Tricolocampium) stenozona Haeckel, 1887; North Pacific Station 256.

? Tricolocampe (Tricolocampium) amphizona Haeckel, 1887; Tropical Atlantic Station 348.

(Note: The last four species listed above may represent a new genus.)

Tricolocampe (Tricolocamptra) urnula Haeckel, 1887; Central Pacific Stations 270 to 274.

?Tricolocampe (Tricolocamptra) doliolum Haeckel, 1887; Eocene-Oligocene, Barbados.

Tricolocampe (Tricolocamptra) cingulata Haeckel, 1887; fossil in Barbados and Sicily; Atlantic Station 348, Central Pacific Station 268.

Tricolocampe (Tricolocampium?) minuta Campbell and Clark, 1944; lower Maestrichtian, California.

Tricolocampe (Tricolocamptra) altamontensis Campbell and Clark, 1944; lower Maestrichtian, California.

Theocampe (Theocampana) vanderhoofi Campbell and Clark, 1944; lower Maestrichtian, California.

Theocampe (Theocamptra) latipunctata, Campbell and Clark, 1944; lower Maestrichtian, California.

Tricolocampe (Tricolocamptra) sanpedroana Campbell and Clark, 1944; Tortonian, Valmonte diatomite, California.

Genus Tricolocampe Haeckel, 1882, emend. Burma

Type species: Tricolocampe clepsydra Rüst, 1885, designated(?) here(?).

Derivation and gender: Greek - caterpillar with three joints, feminine.

Definition: Unidentifiable except as a theocorythid. Monotypic, to be abandoned.

Geologic range: Jurassic.
Genus Diabolocampe Burma, new genus

Eucyrtidium auct. (pars).

Theocampe (T.) auct. (pars).

Theocampe (Theocamptra) auct. (pars).

Type species: Theocampe stenostoma Haeckel, 1887 (p. 1423, pl. 66, fig. 23), here designated.

Derivation and gender of name: Greek - devilish caterpillar, feminine.

Definition: Theocorythids without a cephalic horn; surface smooth to papillate in species now referred to the genus, but could contain species with stronger ornamentation. The three segments are well marked and do not tend to fuse as in Theocampe. Pores typically on all segments, quincuncial arrangement usual but may be irregular. Cephalis usually relatively large for radiolarians; chambers increase in size in fairly regular progression. Abdomen usually inflated, may be only moderately so, but not cylindrical or subcylindrical. Mouth definitely constricted but not on a hyaline collar as in Theocampe. Pores tend to be close-set, so that the test does not appear glassy, in the manner of Theocampe.

Known range: Type species probably from the Tertiary of the Pacific floor; Eocene to Miocene, Recent(?), cosmopolitan.

Species presently referred to the genus:

Theocampe sphaerothorax Haeckel, 1887; Central Pacific Stations 263-274.

Eucyrtidium versipellis Ehrenberg, 1873; Eocene-Oligocene, Barbados.

Eucyrtidium cryptocephalum Ehrenberg, 1873; EoceneOligocene, Barbados.

Theocampe (Theocamptra) pavonis Clark and Campbell, 1945; Bartonian-Ludian, Kreyenhagen shale, California.

The following tabulation is meant to assist those who have a copy of the "Treatise on Invertebrate Paleontology - (D) Protista 3" (Campbell, 1954). Figure numbers are those of the "Treatise."

Figure Genus (according Genus and species no. to Campbell) (according to Burma)

64-4 Cryptocephalus Sethamphorus favosus

64-3 Platycryphalus Dictyocephala (D.) pumila (Rüst)

69-6 Theocampe

69-7 Tricolocampe

Diabolocampe stenostoma (Haeckel)

Theocampe cylindrica

(Haeckel)

\section{ACKNOWLEDGMENT}

The author wishes to thank the officials of the California Exploration Company for permission to publish this paper. 
BIBLIOGRAPHY

$\rightarrow$ CAMpbell, A. S.

1953 - A new radiolarian genus. Jour. Pal., vol. 27, no. 2, p. 296.

1954 - Radiolaria. In: Ciampbell, A. S., and Moore, R. C., Treatise on invertebrate paleontology. New York and Lawrence: Geol. Soc. Amer. and Univ. Kansas Press, Part D (Protista 3), pp. 11-163, text-figs. 6-86.

Gampbell, A. S., and Glark, B. L.

$1944 a$ Miocene radiolarian faunas from southern California. Geol. Soc. Amer., Spec. Paper, no. 51, 76 pp., 7 pls.

$1944 b$ Radiolaria from the Upper Cretaceous of Middle California. Geol. Soc. Amer., Spec. Paper, no. 57, 61 pp., 8 pls.

Clark, B. L., and Campbell, A. S.

1942 - Eocene radiolarian faunas from the Mt. Diablo area, California. Geol. Soc. Amer., Spec. Paper, no. 39, 112 pp., 9 pls.

1945 - Radiolaria from the Kreyenhagen formation near Los Banos, California. Geol. Soc. Amer., Mem., no. 10, 66 pp., 7 pls.

EhrenberG, G.

1854 - Mikrogeologie (Radiolaria on plates 18 to 22, 35, 36).

$1860 a$ Über die organischen und unorganischen Mischungsverhältnisse des Meeresgrundes in 19800 Fu $\beta$ Tiefe nach Lieut. Brookes Messung. K. Preuss. Akad. Wiss., Monatsber., pp. 765-775.
$1860 b$ Über den Tiefgrund des stillen Oceans zwischen Californien und den Sandwich-Inseln aus bis 15600' Tiefe nach Lieut. Brooke. K. Preuss. Akad. Wiss., Monatsber., pp. 819-833.

1872 - Mikrogeologische Studien über das kleinste Leben der Meeres-Tiefgründe aller Zonen und dessen geologischen Einflu $\beta$. K. Preuss. Akad. Wiss., Abh., new species listed described in K. Preuss. Akad. Wiss., Monatsber., pp. 300-321.

1873 - Polycystinen-Mergel von Barbados. K. Preuss. Akad. Wiss., Monatsber., pp. 213-263.

HAECKel, E.

1882 - Prodromus systematis Radiolarium. Jenaische Zeitschr. Naturw., vol. 15, pp. 418-472.

1887 - Report on the Radiolaria collected by H.M.S. Challenger during the years 1873-76. Challenger Exped. 1873-76, Rept., Zool., vol. 18, 3 parts, 1803 pp., 140 pls.

RIEDEL, W. R.

1957 - Eocene Radiolaria. U. S. Geol. Survey, Prof. Paper, no. 280-G, pp. 257-263, pls. $62-63$.

RüsT, D.

1885 - Beiträge zur Kenntnis der fossilen Radiolarien aus Gesteinen der Fura. Palaeontographica, vol. 31, pp. 273321,20 pls.

ZITTEL, K. A.

1876 - Über einige fossile Radiolarien aus der norddeutschen Kreide. Deutsch. Geol. Ges., Zeitschr., vol. 28, pp. 75-86, pl. 2. 